Bangladesh J. Bot. 43(2): 163-168, 2014 (September)

\title{
ACHENE CHARACTERISTICS OF TURKISH CENTAUREA (ASTERACEAE) AND THEIR SYSTEMATIC APPLICATION
}

\author{
Mehmet BonA* \\ Department of Pharmaceutical Botany, Pharmacy Faculty, İstanbul University, İstanbul, Turkey
}

Key words: Centaurea, SEM, Achene, Morphology, Compositae, Asteraceae

\begin{abstract}
This article investigates the exomorphic characteristics of the achenes which are achene size, color, and surface pattern, and pappus length, and colour. All these characteristics in seven taxa of Asteraceae namely, C. aggregata Fisch. \& C.A. Mey. ex DC. subsp. aggregata, C. sivasica Wagenitz, C. polypodiifolia Boiss. var. polypodiifolia, C. polypodiifolia Boiss. var. szowitziana (Boiss.) Wagenitz, C. iberica Trev. ex Spreng, C. urvillei DC. subsp. stepposa Wagenitz, and C. carduiformis DC. subsp. carduiformis var. carduiformis in are described, illustrated and compared. The results of SEM at higher magnification showed three types of achene surface patterns: glebulate-ruminate, smooth, and rugose. In these patterns, there were diagnostic characteristics and differences at the specific level for Centaurea. A key to the taxa has been provided on the basis of these achene characteristics.
\end{abstract}

\section{Introduction}

The genus Centaurea L. (Asteraceae) has about 800 species in the Mediterranean area with SW Asia as its center of diversity (Wagenitz and Hellwig 1996). The genus was revised by Wagenitz (1975) for the Flora of Turkey in which 172 species plus six imperfectly known species were accepted. Turkey is one of the main centers of diversity of the genus (Wagenitz 1975). Here it is the third largest genus in terms of species number in Turkey. Centaurea s.l. has 217 species and endemism ratio is $66.8 \%$ in Turkey (Wagenitz 1975, Davis 1988, Güner et al. 2000, Özhatay et al. 2006, 2009, 2011). Recently, Centaurea L. has been divided into four genera (Wagenitz and Hellwig 2000, Greuter 2003a,b). The revised genera are Centaurea, Rhaponticoides Vaill., Psephellus Cass. and Cyanus Mill.

The traditional delimitation of Centaurea as a genus is problematical, because it results obviously in a non-monophyletic taxon (Garcia-Jacas et al. 2000, 2001). Therefore, since Wagenitz (1955) there has been increased interest in the phylogeny and evolution of characters of "Centaurea" and the subtribe Centaureinae, including floral and achene micromorphology, pollen morphology, karyology and as the most promising approach, DNA sequences (Bancheva and Greilhuber 2006).

This study examined the exomorphic characteristics of 7 Centaurea sensu lato seeds by using Scanning Electron Microscope (SEM) to highlight achene surface ornamentation.

\section{Materials and Method}

Mature achenes of 7 taxa of the genus Centaurea collected from their natural habitats in Turkey in 2012. The specimens collected were kept in the Herbarium (ISTE) of the Department of Pharmaceutical Botany Herbarium, Istanbul University (ISTE). The localities and voucher numbers of the taxa studied are given in Table 1. During Scanning Electron Microscopy (SEM), mature achenes $(2-3)$ from each of the taxa were selected and mounted onto stubs with doublesided adhesive tape, and were then coated with gold. The achene surfaces were examined from the

\footnotetext{
*Author for correspondence: <mehmetbona@gmail.com>.
} 
lateral sides. For each sample, photographs of testa were taken using the JEOL Neoscope 5000 at a magnification of $22 \times, 500 \times, 1000 \times, 2000 \times$ and $3000 \times$. The terminology of achene characteristics in this work was based on the descriptions used by Stearn (1992), Bartholtt (1981) and Koul et al. (2000).

The present study showed three different types of seed surface patterns. These are: glebulateruminate: a type intermediate between glebulate and ruminate (very uneven and looking as if chewed with rounded elevations), smooth: not rough, rugose: wrinkled, the irregular elevations making up the wrinkles and running mostly in one direction.

Table 1. Localities and voucher numbers of studied Centaurea taxa.

\begin{tabular}{lll}
\hline Taxa & Localities & Voucher numbers \\
\hline C. aggregata subsp. aggregata & Kahramanmaraş & ISTE 99184 \\
C. sivasica & Sivas & ISTE 99195 \\
C. polypodiifolia var. polypodiifolia & Sivas & ISTE 99192 \\
C. polypodiifolia var. szowitziana & Sivas & ISTE 99196 \\
C. iberica & Kahramanmaraş & ISTE 99187 \\
C. urvillei subsp. stepposa & Kahramanmaraş & ISTE 99188 \\
C. carduiformis subsp. carduiformis var. carduiformis & Sivas & ISTE 99200 \\
\hline
\end{tabular}

\section{Results and Discussion}

SEM studies show that fruit, seed, and leaf surface patterns are useful taxonomic characteristics for different families and genera of angiosperms (Bona 2013). Fruit and seed characteristics should be critically evaluated in the light of molecular and other morphological data (Moazzeni et al. 2010). The results of the present investigation showed that the achene sizes of the studied taxa were $2-6 \times 1.5-3.0 \mathrm{~mm}$, and pappus length were $0.5-10 \mathrm{~mm}$ except. $C$. sivasica without any pappus. Achene surface is sparsely pilose. Testa cells are regularly arranged and elongated parallelly with the seed surface. Cell boundaries are soft lined.

Achene exomorphic characteristics including achene size, color and surface pattern and pappus length and colour are presented in Table 2.

The results of the studied taxa are discussed below, followed by a key prepared on the basis of the achene characteristics.

C. aggregata Fisch. \& C.A. Mey. ex DC. subsp. aggregata: Achene greenish-brown, 2.5-3 $\times$ $1.5 \mathrm{~mm}$, pappus white, $2 \mathrm{~mm}$ long. Seed surface pattern is glebulate-ruminate. The cell boundaries are very thin and the centers of the cells are higher than the boundaries (Fig. 1).

C. sivasica Wagenitz: Achene greenish-brown when young, later black, 2.5-3.5 $\times 1.5 \mathrm{~mm}$, without pappus. Seed surface pattern is glebulate-ruminate. The cell boundaries are broad and have smooth structure and the boundaries seem higher than the cell center. Testa cells are slightly on the front of the cell (Fig. 1).

C. aggregata subsp. aggregata and C. sivasica were placed under Section Acrolophus by Wagentiz (1975). C. aggregata subsp. aggregata is a widespread taxon which is also distributed in N.W. Iran, W. Iran and N. Iraq (Wagenitz 1975). C. sivasica is an endemic species which is located only around Sivas and Kayseri in Turkey. Only these two taxa have glebulate-ruminate achene surface patterns in the studied taxa. 
C. polypodiifolia Boiss. var. polypodiifolia: Achene grey-white when young, later greyishblack, 5-6 $\times$ 2-2.5 mm, pappus white, 7-8 $\mathrm{mm}$ long. Seed surface pattern is smooth. The cell boundaries are thin and the centers of the cells are placed at equal levels with the boundaries (Fig. 1).

Table 2. Achene characteristics of studied Centaurea taxa.

\begin{tabular}{|c|c|c|c|c|c|}
\hline \multirow[t]{2}{*}{ Taxa } & \multicolumn{2}{|c|}{ Pappus } & \multicolumn{3}{|c|}{ Achene } \\
\hline & Length (mm) & Color & Size $(\mathrm{mm})$ & Color & Pattern \\
\hline $\begin{array}{l}\text { C. aggregata subsp. } \\
\text { aggregata }\end{array}$ & 2 & White & $2.5-3 \times 1.5$ & $\begin{array}{l}\text { Greenish- } \\
\text { brown }\end{array}$ & $\begin{array}{l}\text { Glebulate- } \\
\text { ruminate }\end{array}$ \\
\hline C. sivasica & Absent & Absent & $2.5-3.5 \times 1.5$ & black & $\begin{array}{l}\text { Glebulate- } \\
\text { ruminate }\end{array}$ \\
\hline $\begin{array}{l}\text { C. polypodiifolia var. } \\
\text { polypodiifolia }\end{array}$ & $7-8$ & White & $5-6 \times 2-2.5$ & $\begin{array}{l}\text { Grey-white or } \\
\text { Greyish-Black }\end{array}$ & Smooth \\
\hline $\begin{array}{l}\text { C. polypodiifolia var. } \\
\text { szowitziana }\end{array}$ & $7-8$ & Brownish & $4-5 \times 2-3$ & Brownish & Smooth \\
\hline C. iberica & $0.5-1$ & White & $2-3 \times 1.5-2$ & $\begin{array}{l}\text { Light to dark } \\
\text { brown }\end{array}$ & Rugose \\
\hline C. urvillei subsp. stepposa & $7-9$ & Brownish & $4-6 \times 2.5-3$ & $\begin{array}{l}\text { Silvery to } \\
\text { yellowish }\end{array}$ & Smooth \\
\hline $\begin{array}{l}\text { C. carduiformis subsp. } \\
\text { carduiformis var. } \\
\text { carduiformis }\end{array}$ & $8-10$ & Silvery & $5-6 \times 2.5-3$ & Silvery & Smooth \\
\hline
\end{tabular}

C. polypodiifolia Boiss. var. szowitziana (Boiss.) Wagenitz: Achene yellowish when young, later brown (ones or two greyish black), $4-5 \times 2-3 \mathrm{~mm}$, pappus brownish, $7-8 \mathrm{~mm}$ long. Seed surface pattern is smooth. The cell boundaries are very thin and the centers of the cells are higher than the boundaries. Testa cells are on the front of the cells. This condition shows itself as waved layers (Fig. 1).

C. polypodiifolia var. polypodiifolia and C. polypodiifolia var. szowitsiana were placed under Section Microlophus by Wagenitz (1975). These two taxa are separated from each other based on a few morphological characteristics of involucre width and leaf shape (Wagenitz 1975). This study shows that seed characteristics are useful in the separation of these taxa. Smooth achene patterns show differentiation in detailed investigations with high magnification. The cell boundaries are thin and the centers of the cells are placed at equal level with the boundaries in C. polypodiifolia var. polypodiifolia. The cell boundaries are very thin and the centers of the cells are higher than the boundaries. Testa cells are on the front of the cell. This condition shows itself as waved layers in C. polypodiifolia var. szowitsiana. Beside this C. polypodiifolia var. polypodiifolia has white pappus and grey-white or greyish-black achene but C. polypodiifolia var. szowitsiana has brownish pappus and achene.

C. iberica Trev. ex Spreng: Achene mostly light brown, sometimes darker, 2 - $3 \times 1.5-2 \mathrm{~mm}$, pappus white, $0.5-1 \mathrm{~mm}$ long. Seed surface pattern is rugose. The cell boundaries are broad and the boundaries seem higher than the cell center (Fig. 2).

C. iberica is the only specimen that has rugose seed surface pattern. The taxon was placed under Section Calcitrapa by Wagenitz (1975). 
C. urvillei DC. subsp. stepposa Wagenitz: Achene silvery when young, later yellowish, 4 - 6 $\times 2.5-3 \mathrm{~mm}$, pappus brownish, $7-9 \mathrm{~mm}$ long. Seed surface pattern is smooth. The cell boundaries are very thin and the centers of the cells are slightly higher than the boundaries. Testa cells are slightly on the front of the cell (Fig. 2).
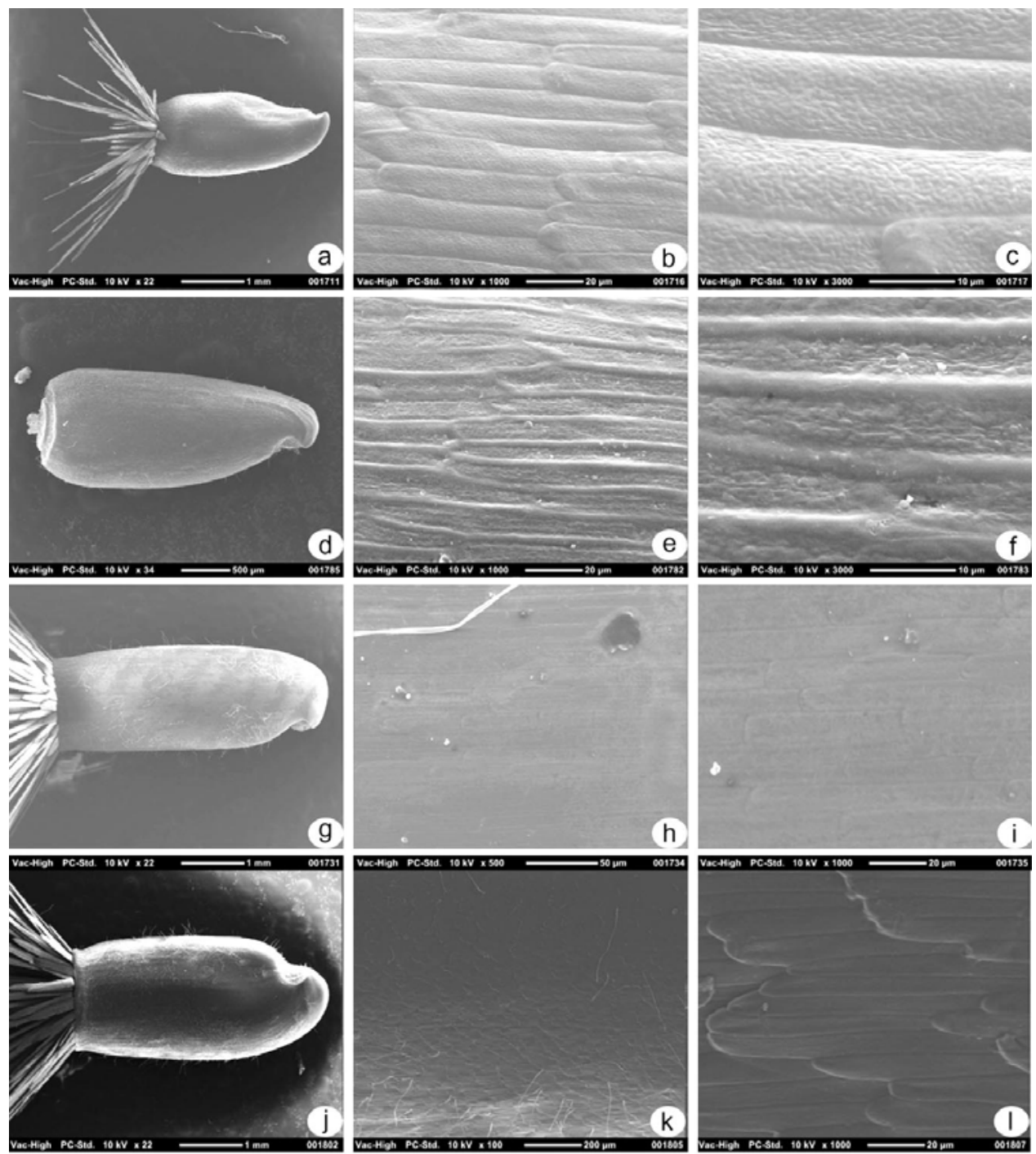

Fig. 1. SEM micrographs of achenes of Turkish Centaurea. C. aggregata subsp. aggregata (a-c), C. sivasica (d-f), C. polypodiifolia var. polypodiifolia (g-i), C. polypodiifolia var. szowitsiana (j-1).

C. carduiformis DC. subsp. carduiformis var. carduiformis: Achene silvery, $5-6 \times 2.5-3$ $\mathrm{mm}$, pappus silvery, $8-10 \mathrm{~mm}$ long, inner row different, c. $2 \mathrm{~mm}$ long. Seed surface pattern is smooth. The cell boundaries are very thin and the centers of the cells are slightly higher than the boundaries. Testa cells are sulcate and slightly on the front of the cell (Fig. 2). 
The endemic taxa, C. urvillei subsp. stepposa and C. carduiformis subsp. carduiformis var. carduiformis were placed under Section Acrocentron by Wagenitz (1975). C. carduiformis subsp. carduiformis var. carduiformis has silvery pappus and sulcate testa cells and because of this it is easily separated from all other specimens.
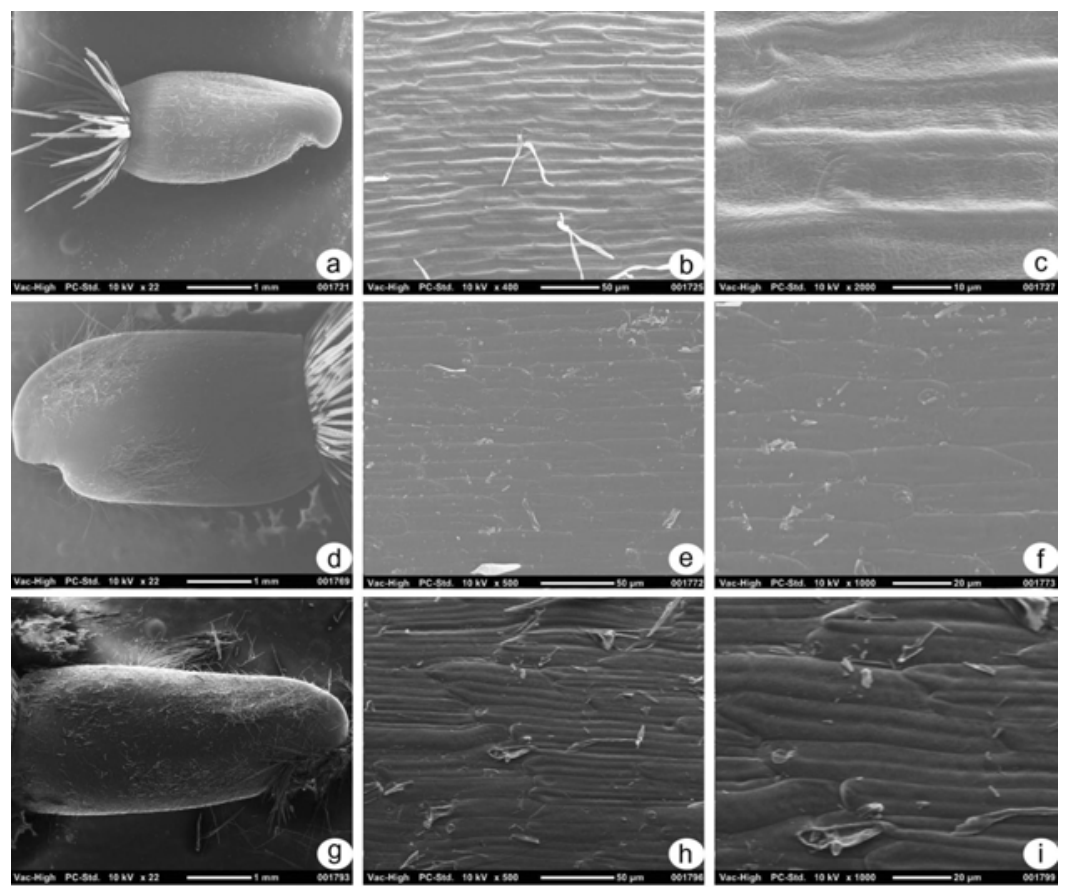

Fig. 2. SEM micrographs of achenes of Turkish Centaurea. C. iberica (a-c), C. urvillei subsp. stepposa (d-f), C. carduiformis subsp. carduiformis var. carduiformis (g-i).

\section{Key to the studied taxa according to achene characteristics}

1.Pappus absent

C. sivasica

1.Pappus present

2. Pappus white

3. Pappus up to $7 \mathrm{~mm}$ long

3. Pappus up to $2 \mathrm{~mm}$ long

4. Seed surface pattern glebulate-ruminate

4. Seed surface pattern rugose

C. polypodiifolia var. polypodiifolia

C. aggregata subsp. aggregata

C. iberica

2. Pappus not white

5. Achene brownish

C. polypodiifolia var. szowitsiana

5. Achene not brownish

6. Pappus silvery

6. Pappus brownish

C. carduiformis subsp. carduiformis var. carduiformis

C. urvillei subsp. stepposa

In conclusion, this study supports the use of achene surface patterns as diagnostic characteristics at species and subspecies levels for the genus Centaurea s.l. Furthermore, achene surface pattern seems to be useful at sectional level because of glebulate-ruminate patterns in 
Section Acrolophus. There are other achene characteristics like achene length and colour, pappus length and colour that might be helpful to distinguish certain more taxa. However, through achene characteristics provide strong support in the delimitation of the studied taxa at specific level, understanding the importance of these characteristics at generic and subgeneric levels requires further study.

\section{References}

Bancheva S and Greilhuber J 2006. Genome size in Bulgaria Centaureas.1. (Asteraceae). Plant Syst. Evol. 257: $95-117$.

Barthlott W 1981. Epidermal and seed surface characters of plants: systematic applicability and some evolutionary aspects. Nord. J. Bot. 1: 345-355.

Bona M 2013. Seed-coat microsculpturing of Turkish Lepidium (Brassicaceae) and its systematic application. Turk. J. Bot. 37: 662-668.

Davis PH 1988. Flora of Turkey and The East Aegean Islands Volume 10, pp. 166-169. Edinburgh University Press, Edinburgh.

Garcia-Jacas N, Susanna A, Garnatje T and Vilatersana R 2001. Generic delimitation and phylogeny of the subtribe Centaureinae (Asteraceae): a combined nuclear and chloroplast DNA analysis. Ann. Bot. 87: 503-515.

Garcia-Jacas N, Susanna A, Mozaffarian R and İlarslan R 2000. The natural delimitation of Centaurea (Asteraceae: Cardueae): ITS sequence analysis of the Centaurea jacea group. Pl. Syst. Evol. 223: 185199.

Greuter W 2003a. The Euro+Med treatment of Cardueae (Compositae) -generic concepts and required new names. Willdenowia 33: 49-61.

Greuter, W 2003b. The Euro+Med treatment Senecioneae and the minor Compositae tribes-generic concepts and required new names, with an addentum to Cardueae. Willdenowia 33: 245-250.

Güner A, Özhatay N, Ekim T, \& Başer KHC 2000. Flora of Turkey and The East Aegean Islands Volume 11, pp. 163-164. Edinburgh University Press, Edinburgh.

Koul KK, Nagpal R and Raina SN 2000. Seed coat microsculpturing in Brassica and allied genera (subtribeBrassicinae, Raphaninae, Moricandiinae). Ann. Bot. 86: 385-397.

Moazzeni H, Zarre S, Al-Shehbaz IA and Mummenhof K 2010.Phylogeny of Isatis (Brassicaceae) and allied genera based on ITS sequences of nuclear ribosomal DNA and morphological characters. Flora 205: 337-343.

Özhatay N and Kültür Ş 2006. Check list of additional taxa to the Supplement Flora of Turkey III. Turk. J. Bot. 30: 281-316.

Özhatay N, Kültür Ş and Aslan S 2009. Check list of additional taxa to the Supplement Flora of Turkey IV. Turk. J. Bot. 33: 191-226.

Özhatay N, Kültür Ş and Gürdal B 2011. Check-list of additional taxa to the Supplement Flora of Turkey V. Turk. J. Bot. 35: 589-624.

Stearn WT 1992. Botanical Latin. David \& Charles Pub., London.

Wagenitz G and Hellwig FH 1996.Evolution of characters and phylogeny of Centaureinae. In: Compositae. Systematics. Proceedings of the International Compositae Conference, Hind DJN andBeentje HJ (Eds.) Kew, 1994, vol. 1. Royal Botanic Gardens, Kew, pp. 491-510.

Wagenitz G 1955.Pollen morphologie und systematik in der gattung Centaurea L. s.l. Flora 142: 213-279.

Wagenitz G 1975. In Davis P H, ed. Flora of Turkey and The East Aegean Islands Volume 5, pp. 465-585. Edinburgh University Press, Edinburgh.

Wagenitz G and Hellwig FH 2000. Psephellus Cass. (Compositae, Cardueae) revisited with a broadened concept. Willdenowia 30: 29-44.

(Manuscript received on 27 July, 2013; revised on 17 February, 2014) 